\title{
Article \\ Molecular and Biochemical Characterization, Antimicrobial Activity, Stress Tolerance, and Plant Growth-Promoting Effect of Endophytic Bacteria Isolated from Wheat Varieties
}

\author{
Dawood Shah ${ }^{1,2}$, Mohammad Sayyar Khan ${ }^{1}$, Shahkaar Aziz ${ }^{1}$, Haidar Ali ${ }^{1}$ and Lorenzo Pecoraro ${ }^{2, *(D)}$ \\ 1 Institute of Biotechnology and Genetic Engineering, The University of Agriculture Peshawar, \\ Peshawar 25000, Pakistan; dawoodshah616@gmail.com (D.S.); sayyarkhankazi@aup.edu.pk (M.S.K.); \\ shahkaaraziz@aup.edu.pk (S.A.); haider@aup.edu.pk (H.A.) \\ 2 School of Pharmaceutical Science and Technology, Tianjin University, 92 Weijin Road, Tianjin 300072, China \\ * Correspondence: lorenzo.pecoraro@tju.edu.cn; Tel.: +86-185-2082-4550
}

Citation: Shah, D.; Khan, M.S.; Aziz, S.; Ali, H.; Pecoraro, L. Molecular and Biochemical Characterization, Antimicrobial Activity, Stress Tolerance, and Plant GrowthPromoting Effect of Endophytic Bacteria Isolated from Wheat

Varieties. Microorganisms 2022, 10, 21. https://doi.org/10.3390/ microorganisms10010021

Academic Editor: Francisco

Xavier Nascimento

Received: 23 November 2021

Accepted: 21 December 2021

Published: 23 December 2021

Publisher's Note: MDPI stays neutral with regard to jurisdictional claims in published maps and institutional affiliations.

Copyright: (c) 2021 by the authors Licensee MDPI, Basel, Switzerland. This article is an open access article distributed under the terms and conditions of the Creative Commons Attribution (CC BY) license (https:/ / creativecommons.org/licenses/by/ $4.0 /)$.

\begin{abstract}
Endophytic bacteria have been utilized as an alternative source to chemical fertilizers and pesticides to enhance plant productivity and defense mechanisms against biotic and abiotic stress. Five endophytic bacterial strains were isolated from the seeds of three different Pakistani wheat varieties (Ghaneemat-e-IBGE, Atta-Habib, and Siren). The isolated strains AH-1, S-5, S-7, GI-1, and GI-6 showed phylogenetic similarity with Bacillus altitudinis, B. aryabhattai, B. wiedmannii, Pseudomonas aeruginosa, and Burkholderia gladioli, respectively. All strains showed catalase activity (except AH-1) and Indole-3-acetic acid production, with the highest concentration $\left(16.77 \mu \mathrm{g} \cdot \mathrm{mL}^{-1}\right)$ found for GI6, followed by S-5 (11.5 $\left.\mu \mathrm{g} \cdot \mathrm{mL}^{-1}\right)$, nitrogen assimilation (except S-7), phosphorus solubilization (except S-7 and AH-1), and ability to produce siderophores, with maximum productions for GI-6 $(31 \pm 3.5 \mathrm{psu})$ and GI-1 (30 $\pm 2.9 \mathrm{psu})$. All five analyzed strains possessed antimicrobial activity, which was particularly strong in GI-6 and S-5 against Klebsiella pneumonia, Escherichia coli, and Bacillus subtilis. Increasing salinity stress with $\mathrm{NaCl}$ negatively affected the bacterial growth of all isolates. However, strains GI-6 and S-5 showed salt tolerance after three days of incubation. A drought tolerance test resulted in a negative impact of poly ethylene glycol on bacterial growth, which was, however, less pronounced in GI-6 strain. The GI-6 strain revealed growth-promoting effects on inoculated wheat plants.
\end{abstract}

Keywords: bacterial endophytes; wheat varieties; phylogeny; biochemical analysis; antimicrobial activity; stress tolerance; plant growth-promoting ability

\section{Introduction}

In the wake of the growing world populations and confronting challenges of climate change, eco-friendly applications of biotechnology and plant breeding to enhance agriculture productivity are crucial. Usage of manures, pesticides, and chemical fertilizers are traditional methods to increase soil fertility and crop yields that also negatively impact the environment through fertilizers adsorption, runoff, and hazardous accumulation of chemicals, such as cadmium, in soil [1]. Plant growth-promoting (PGP) microbes are an effective and environmentally sustainable alternative for replacing chemical fertilizers. Over the last few years, researchers have increasingly focused on microbial bio-inoculants as bio-fertilizers and bio-pesticides for sustainable agriculture [2].

Endophytes are microbes that colonize plant tissues without causing any disease symptoms. In typical conditions, endophytes play a vital role in the development and growth of host plants by enhancing the assimilation of nutrients and the production of secondary metabolites, which protect the plant from various disease-causing pathogens. Endophytic microbes such as bacteria and fungi, form a network around their host plants and protect them from unfavorable climatic and other environmental changes [3]. Endophytes enhance plant growth through the fixation of atmospheric nitrogen, uptake of phosphorus, 
potassium, and zinc, the development of $\mathrm{Fe}^{3+}$-chelating molecules and the secretion of different phytohormone (phytostimulation), such as auxins, ethylene, gibberellins, and cytokines [4]. In the endophytic interaction, microbes have an indirect function to control the harmful effect of phytopathogens on plant and soil health via the synthesis of innumerable substances, including immunosuppressants, antibiotics, bio-control agents, hydrogen cyanide $(\mathrm{HCN})$, and ammonia [5].

Several bacteria, including Bacillus sp., Pseudomonas sp., Acinetobacter sp., Azotobacter sp., and Azospirillum sp., generate phytohormone-like cytokinins, indoleacetic acid, octadecanoid acids, and gibberellin compounds that imitate the action of jasmonates and contribute to the survival of the plants. Endophytic bacteria synthesize organic acids to solubilize phosphorus, thus increasing phosphorus supply to the plant [6].

Wheat (Triticum spp.) is one of the world's most valuable crops, providing more calories and proteins than any other grown crop. It is a staple food for over 35\% of the world's population [7]. It is cultivated by approximately $80 \%$ of Pakistani farmers, accounting for nearly $40 \%$ of the total cultivated areas in Pakistan. It is planted on 9151 thousand hectares of land in the country, yielding 25,980 thousand tons of wheat grains at an average yield of $4054 \mathrm{~kg} \mathrm{ha}^{-1}$ [8].

Drought is a global issue that affects almost every wheat-producing area and causes extreme osmotic stress. Global warming is the key factor that persistently increases the problem of drought and associated risk to crop yields [9]. Soil salinization, which threatens around $20 \%$ of arable cropland worldwide, is another source of high osmotic stress for cultivated plants [10]. Soil salinization is becoming a dominant problem in agriculture, with half of all arable cropland expected to be affected by 2050 [10,11]. During the later tillering phases, drought and osmotic stress were found to reduce yield by lowering kernel quantity and slowing plant recovery [12]. Drought negatively affects many additional plant metrics, such as leaf area index, dry matter accumulation, and net absorption rates [13]. Additionally, drought can disrupt metabolic processes such as photosynthesis and impair sugar synthesis, which is essential to drive the wheat yield [14]. A decrease in kernel number and weight was found when salt stress was applied after terminal spikelet growth [15]. Because of the low water content, high salinity disrupts plant selective ion absorption at cellular level, affecting nutrient availability [16].

The molecular identification and ecological characterization of plant-associated microbes are critical to understand the exact role these microorganisms play, their interactions with plants, and to develop effective biotechnological applications using endophytic strains to improve agricultural production [17]. This study aimed to assess the diversity of endophytic bacteria in different wheat varieties collected in Pakistan and to characterize the plant growth-promoting, drought, salt, and disease-resistance traits of the isolated bacterial strains. The analyzed endophytic microbes could be used as biofertilizers and biopesticides to support the development of sustainable agriculture.

\section{Materials and Methods}

\subsection{Isolation of Endophytes}

The seeds of three different indigenous wheat (Triticum aestivum) varieties from Pakistan, namely, Ghaneemat-e-IBGE, Atta-Habib, and Siren were used to isolate endophytic bacteria. Seeds were surface sterilized using $70 \%$ ethanol for $30 \mathrm{~s}$, then washed with $15 \%$ sodium hypochlorite solution for $2 \mathrm{~min}$, followed by rinsing with $70 \%$ ethanol for $30 \mathrm{~s}$. Finally, the seeds were thoroughly rinsed three times with double distilled water. Complete disinfection was checked after incubating $1 \mathrm{~mL}$ of the last seed rinsing water in $10 \mathrm{~mL}$ of liquid broth (LB) media for $48 \mathrm{~h}$. Ten intact disinfected seeds were placed on Petri dishes containing LB and incubated at $24{ }^{\circ} \mathrm{C}$. After 7 days of incubation, the appeared colonies were selected and characterized morphologically. The selected colonies were sub-cultured following the method by [18] to obtain pure cultures. The morphologically distinct endophyte pure colonies were stored at $4{ }^{\circ} \mathrm{C}$. 


\subsection{Identification of Endophytes}

The isolated endophytes were characterized by colony morphology, shape, color, texture, and growth according to the method described by [19]. For Molecular identification, the isolated microbes were cultured in LB broth at $30^{\circ} \mathrm{C}$ for $24 \mathrm{~h}$ in a shaker at $220 \mathrm{rpm}$, and then centrifuged at $4000 \mathrm{rpm}$. The cell pellets were used for bacterial genomic DNA isolation according to optimized protocols [20]. The isolated endophytes were identified based on the amplification of the 16SrRNA gene. A 1500-bp sequence was amplified from genomic DNA using the primers P027F and 1378R specific for the 16S ribosomal RNA genes. In a $25 \mu \mathrm{L}$ PCR mixture, $1 \mu \mathrm{L}(0.5-10.0 \mathrm{ng})$ template DNA, $0.2 \mu \mathrm{M}$ each of primers P027F (5'-GAGAGTTTGATCCTGGCTAG-3) and 1378R (5'-CGGTGTGT ACSSGGCCCG GGAACG-3'), $200 \mu \mathrm{M}$ each dNTP, $10 \times$ buffer, $2 \mathrm{mM} \mathrm{MgSO}_{4}$, and $1 \mathrm{U}$ high-fidelity KOD Taq DNA polymerase were used [21]. The amplification program was as follows: initial denaturation for $4 \mathrm{~min}$ at $94{ }^{\circ} \mathrm{C} ; 30$ cycles of denaturation for $30 \mathrm{~s}$ at $94{ }^{\circ} \mathrm{C}$, annealing for $1 \mathrm{~min}$ at $63^{\circ} \mathrm{C}$, extension for $1 \mathrm{~min}$ at $68^{\circ} \mathrm{C}$, and a final total extension for $7 \mathrm{~min}$ at $68^{\circ} \mathrm{C}$. The PCR was performed in a thermocycler programmed as follows: $94^{\circ} \mathrm{C}$ for $2 \mathrm{~min} ; 35$ cycles of $94{ }^{\circ} \mathrm{C}$ for $45 \mathrm{~s}, 55^{\circ} \mathrm{C}$ for $60 \mathrm{~s}, 72{ }^{\circ} \mathrm{C}$ for $60 \mathrm{~s}$ and final extension for $72{ }^{\circ} \mathrm{C}$ for $10 \mathrm{~min}$. The PCR products were purified and sent to Macrogen, Korea Co. Ltd. for sequencing. BLAST searches of the 16S rRNA sequences obtained from the isolated bacterial strains were performed in the NCBI database. The homologous $16 \mathrm{~S}$ rRNA sequences were aligned using the multiple-sequence alignment tool "CLUSTAL-W" in MEGA 7 software [22]. The phylogenetic tree was constructed using the neighbor-joining and maximum likelihood methods [23].

\subsection{Identification of Siderophore}

The isolated endophytes were characterized for siderophore production using a modified standard method for inoculating bacterial cells in liquid 284 medium with a chrome azurol sulphonate (CAS) shuttle solution, where the siderophore formation was stimulated. In microcentrifuge tubes, approximately $50 \mu \mathrm{L}$ of bacterial suspension in $\mathrm{MgSO}_{4}(10 \mathrm{mM})$ was injected into $800 \mu \mathrm{L}$ of 284 media with three different iron concentrations. Iron concentrations of $0 \mu \mathrm{M}, 0.25 \mu \mathrm{M}$, and $3 \mu \mathrm{M}$ Fe (III) citrate were used. The samples were shaken and incubated at $30{ }^{\circ} \mathrm{C}$ for 5 days $(150 \mathrm{rpm})$. After incubation, $100 \mu \mathrm{L}$ of the blue CAS reagent were added, and the tubes were kept at room temperature for $4 \mathrm{~h}$. Following this step, the shift in color from blue to orange/yellow was regarded as a positive. Both samples had their siderophore concentrations estimated at $630 \mathrm{~nm}$. The siderophore quantities were calculated using the formula: percent of siderophore units (psu) Ar-As/Ar 100, where "Ar" represents the absorbance of the reference (CAS reagent) and "As" represents the absorbance of the sample at $630 \mathrm{~nm}$. In the bacterial isolates, a qualitative test using the CAS agar assay confirmed siderophore formation. In Minimal Media 9, the $\mathrm{FeCl}_{3}$ and HDTMA-containing CAS solution was combined with $20 \%$ glucose, CAS amino acid solution, and bacto-agar (MM9). Bacterial isolates were inoculated onto CAS agar plates and kept at $28^{\circ} \mathrm{C}$ in the dark for two weeks. The appearance of yellow/orange halos around the colonies confirmed the siderophore production.

\subsection{Indole-3-Acetic Acid Production}

The production of indole-3-acetic (IAA) was assayed according to the modified method of Gordon and Weber (1951). It was measured by growing isolates in LB media overnight at $28{ }^{\circ} \mathrm{C}$ with shaking at $220 \mathrm{rpm}$ for $24 \mathrm{~h}$. A total of $2 \mathrm{~mL}$ of supernatant was combined with two drops of orthophosphoric acid and an equal volume of Salkowski's reagent after centrifugation of cell culture [24]. Furthermore, the optical density was measured using a UV spectrophotometer at $535 \mathrm{~nm}$, and the concentration was calculated.

\subsection{Phosphates Solubilization}

The potential strains were streaked using a modified method from [9] for phosphate solubilization on Pikovskaya's agar medium, which contains (per liter): $0.5 \mathrm{~g}$ yeast extract, 
$10 \mathrm{~g}$ dextrose, $5 \mathrm{~g} \mathrm{Ca}_{3}\left(\mathrm{PO}_{4}\right)_{2}, 0.5 \mathrm{~g}\left(\mathrm{NH}_{4}\right)_{2} \mathrm{SO}_{4}, 0.2 \mathrm{~g} \mathrm{KCl}, 0.1 \mathrm{~g} \mathrm{MgSO}_{4} \cdot \mathrm{H}_{2} \mathrm{O}, 0.0001 \mathrm{~g}$ $\mathrm{MnSO}_{4} \cdot \mathrm{H}_{2} \mathrm{O}, 0.0001 \mathrm{~g} \mathrm{FeSO} \cdot \mathrm{H}_{2} \mathrm{O}$. Fifteen strains that produced a clear zone around the colonies after 3 days of incubation at $28{ }^{\circ} \mathrm{C}$ were considered positive. The phosphate solubilization index was calculated by measuring the colony diameter and the halo zone diameter, using the formula: Phosphate Solubilization Index (SI) $=($ Colony diameter + Halo zone diameter)/Colony diameter.

\subsection{Catalase Test}

The catalase presence in the isolates was checked by placing a drop of $3 \% \mathrm{H}_{2} \mathrm{O}_{2}$ and adding the bacterial colony on a glass slide. Bubble formation was regarded as positive, while the absence of bubbles or a few scattered bubbles was regarded as negative [25].

\subsection{Nitrogen Fixation}

Nitrogen fixation capacity was determined by growing the isolated endophytic bacteria in nitrogen-free Ashby medium and Jensen medium [26]. The bacterial strains were inoculated in $5 \mathrm{~mL}$ of Ashby medium (without agar) in a $45 \mathrm{~mL}$ test tube and cultured for 7 days on a rotary shaker $(125 \mathrm{rpm})$ at $28^{\circ} \mathrm{C}$. The bacterial colony growth was also tested on the Jensen medium at $28^{\circ} \mathrm{C}$ for 4 days.

\subsection{Antimicrobial Activity}

The isolated endophytes were used for antimicrobial activity tests against the pathogenic bacteria Klebsiella pneumonia, Escherichia coli, and Staphylococcus aureus, and the non-pathogenic bacterium Bacillus subtilis. The disc diffusion method was applied to perform the antimicrobial bioassays, using two-day-old cultures of the selected pathogenic bacterial strains. The endophytic bacterial culture was spot-inoculated at three equidistant points of the LB agar plate, about $2.5 \mathrm{~cm}$ away from the middle, with 5,10 , and $15 \mu \mathrm{L}$ doses. A $6 \mathrm{mM}$ microbial plug was mounted in the plate's middle, and the plates were incubated at $28^{\circ} \mathrm{C}$. Plates containing endophytes without bacterial inoculation were used as a negative control. The pathogen's growth against the endophytic bacterial strain was monitored on a regular basis. The zone of inhibition of pathogenic growth was measured after the control plates reached the plate edges. The following formula was used to calculate the pathogen's growth inhibition: ((C-T)/C) 100, where C represents the test pathogen's radial growth in the control plates $(\mathrm{mm})$ and T represents the test pathogen's radial growth in the test plates. Ciprofloxacin was used a positive control.

\subsection{Analysis of Endophytic Strain Tolerance to Drought and Salt Stresses}

The growth of the selected bacterial isolates was analyzed at various stress levels following the method by Pirhadi et al. [27]. Trypticase soy broth (TSB) was supplemented with different poly ethylene glycol (PEG) concentrations, including the $0,2.5 \%, 5 \%, 7.5 \%$, and $10 \%$ PEG, to screen the isolates for drought-stress tolerance. The different media were inoculated with isolated strains' overnight grown broth cultures with an adjusted optical density (OD) of 0.1 at $600 \mathrm{~nm}$. The growth of the isolates at various stress levels was estimated by measuring the $\mathrm{OD}$ at $600 \mathrm{~nm}$ after incubation at $28{ }^{\circ} \mathrm{C}$ for $24 \mathrm{~h}$ [28]. The salt tolerance capacity of each isolate overnight culture was dropped in triplicate on nutrient agar plates containing different concentrations of $\mathrm{NaCl}(0,50,100,150$, and $200 \mathrm{mM})$ and incubated at $30{ }^{\circ} \mathrm{C}$ for three days. The colony's diameter was measured regularly. Colony growth was compared, and a control inoculum was performed without any salt added. The percentage reduction in growth in salt-amended media was determined using the following formula:

$$
(100 \times \mathrm{A}-\mathrm{B} / \mathrm{A})
$$

where A represents colony diameter growth in the control plate, in $\mathrm{mm}$, of the isolate and $\mathrm{B}$ represents colony diameter growth in the salt amended plate in $\mathrm{mm}$ [26]. 


\subsection{Pot Experiment for Evaluating Plant Growth-Promoting Effect of Isolated} Endophytic Bacteria

A completely randomized design was used to analyze the isolated endophyte strain GI-6 for growth-promoting effect on the Triticum aestivum cultivar Imdad in a controlled greenhouse environment. The endophyte was cultured overnight in $5 \mathrm{~mL} \mathrm{LB}$, transferred in $50 \mathrm{~mL} \mathrm{LB}$ broth for $24 \mathrm{~h}$ at $30{ }^{\circ} \mathrm{C}$ with $220 \mathrm{rpm}$ shaking, re-inoculated in $400 \mathrm{~mL} \mathrm{LB}$ and incubated for another $24 \mathrm{~h}$ at $30^{\circ} \mathrm{C}$. A spectrophotometer was used to determine the culture's optical density (OD) $(600 \mathrm{~nm})$. The culture was then diluted ten times with tap water, and seeds of the wheat variety (Imdad) were soaked in the diluted culture for around $40 \mathrm{~min}$ before being used as controls. Non-inoculated seeds of the studied wheat variety were soaked in ten times-diluted LB broth. Morphological observation of agro-phenotype characters of the cultivar, including plant height, spike length, leaf length, root length, and number of grains per spike, was performed.

\subsection{Graphical and Statistical Analysis}

The obtained data were statistically analyzed through ANOVA, MEGA 7, BLAST, SPSS, and Pub gene 3.2 software packages.

\section{Results}

In the current study, five endophytic bacteria were isolated from the seeds of the different investigated wheat varieties. The isolated strains, named AH-1, S-5, S-7, GI-1, and GI-6, were morphologically and molecularly identified as Bacillus altitudinis, B. aryabhattai, B. wiedmannii, Pseudomonas aeruginosa, and Burkholderia gladioli, respectively (Figures 1 and 2).

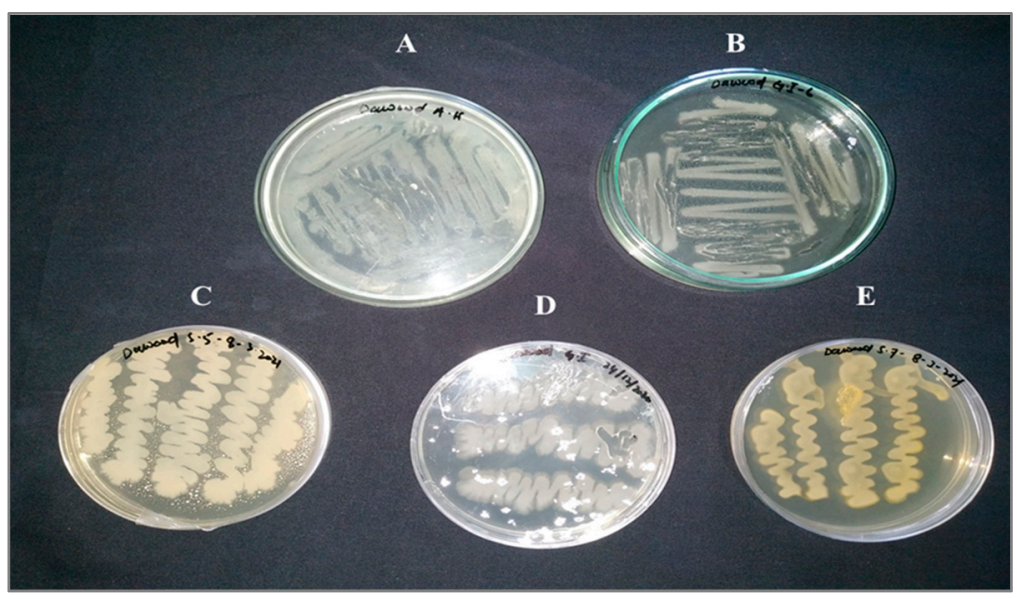

Figure 1. Colony morphology of the analyzed endophytic bacterial strains on LB agar plates: (A) Atta Habib (AH-1), (B,C) Ghaneemat-e-IBGE (GI-1, GI-6), (D,E) Sirin-5, Sirin-7.

Molecular analysis indicated that the isolated strains belonged to the genera Bacillus, Pseudomonas, and Burkholderia. Based on BLAST search in NCBI, the strains S-5 and S-7 showed 100\% similarity with Bacillus aryabhattai and B. wiedmannii, respectively (Table 1). The strain AH-1 exhibited $99.97 \%$ similarity with Bacillus altitudinis, while GI-1 and GI-6 showed similarity with Pseudomonas aeruginosa (99.80\%) and Burkholderia gladioli (99.70\%), respectively (Table 1). The maximum-likelihood approach was used to determine the phylogenetic relationship between the selected database sequences. Isolate AH-1 was found in the same cluster with isolate S-5, and was closely related to Bacillus altitudinis and $B$. aryabhattai. Isolate S-7 was close to $B$. wiedmannii, while isolates GI-1 showed phylogenetic similarity with Pseudomonas aeruginosa (Figure 3). 


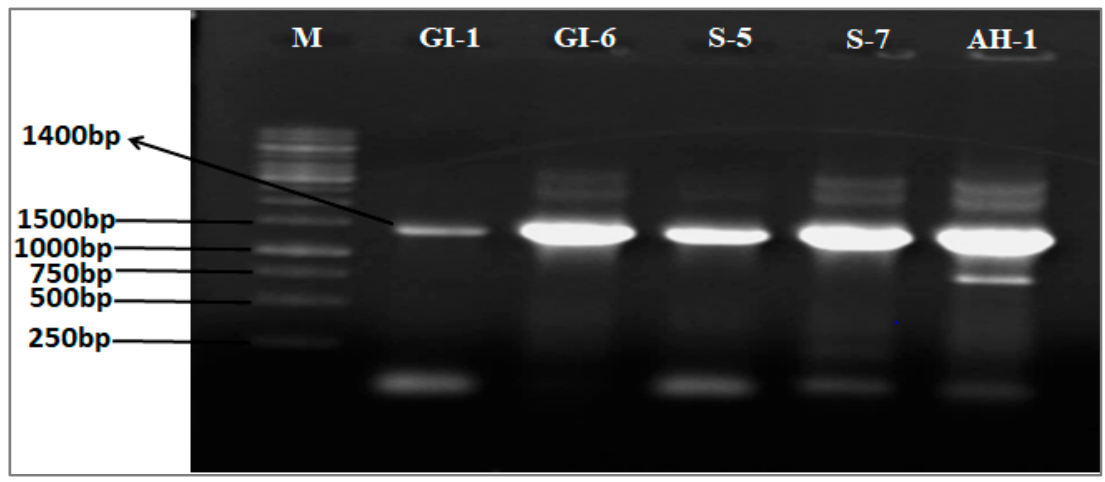

Figure 2. Agarose gel analyses (1\% agarose, $w / v)$ of amplified $16 \mathrm{~S}$ RNA of the isolates used in the study. (Lane $\mathrm{M}$ = marker; lane 1 = GI-1; lane 2 = GI-6; lane 3 = S-5; lane 4 = S-7; lane 5 = AH-1).

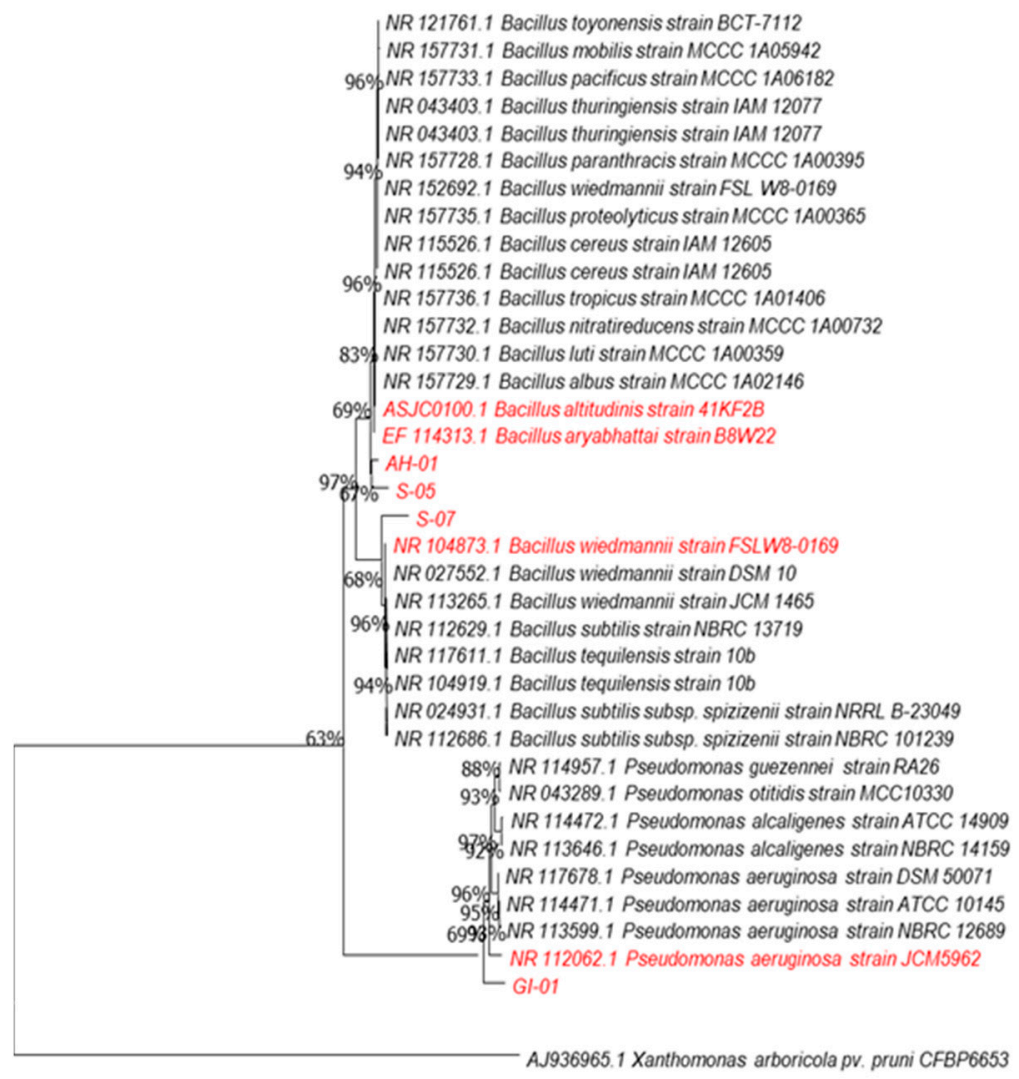

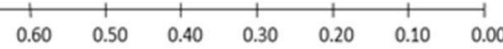

Figure 3. The $16 \mathrm{~S}$ rRNA gene sequences of bacteria GI-01, S-07, S-05, and AH-01, as well as related bacteria in the genera Pseudomonas and Bacillus, were used to create a maximum-likelihood phylogenetic tree. The phylogenetic relationship was deduced using the Tamura-Nei model and the maximum likelihood approach (1993). Bootstrap values are expressed as a percentage of 1000 replicates; values less than 50\% are not given. Xanthomonas arboricola pv. pruni strain CFBP6653, AJ936965.1 was used as outgroup. Sequences from the analyzed endophytic bacterial strains and from their best matches are in red. 
Table 1. Identification of the endophytic bacteria isolated from wheat varieties.

\begin{tabular}{cccccc}
\hline Bacterial Strains & Wheat Variety & BLAST Matches & $\begin{array}{c}\text { Top-Hit Strain with } \\
\text { Accession Number }\end{array}$ & Similarity (\%) & Completeness (\%) \\
\hline AH-1 & Atta-Habib & Bacillus altitudinis & $\begin{array}{c}41 \mathrm{KF} 2 \mathrm{~b}(\mathrm{~T}) \\
\text { ASJC01000029 } \\
\text { B8W22(T) }\end{array}$ & 99.97 & 100 \\
S-5 & Siren & Bacillus aryabhattai & EF114313 & 100.0 & 100 \\
& Siren & Bacillus wiedmannii & FSL W8-0169(T) & 100.0 & 100 \\
S-7 & LOBC01000053 & JCM 5962(T) & 99.80 & 100 \\
GI-1 & Ghaneemat-e- & Pseudomonas & Beruginosa & BAMA01000316 & NBRC 13700 (T) \\
GI-6 & Ghaneemat-e- & Burkholderia gladioli & BBJG01000151 & 99.70 & 100 \\
\hline
\end{tabular}

Similarly, a maximum-likelihood phylogenetic tree was constructed for Burkholderia genus, showing that the isolate GI-6 formed a clade with the B. gladioli with a bootstrap value of 71 (Figure 4).

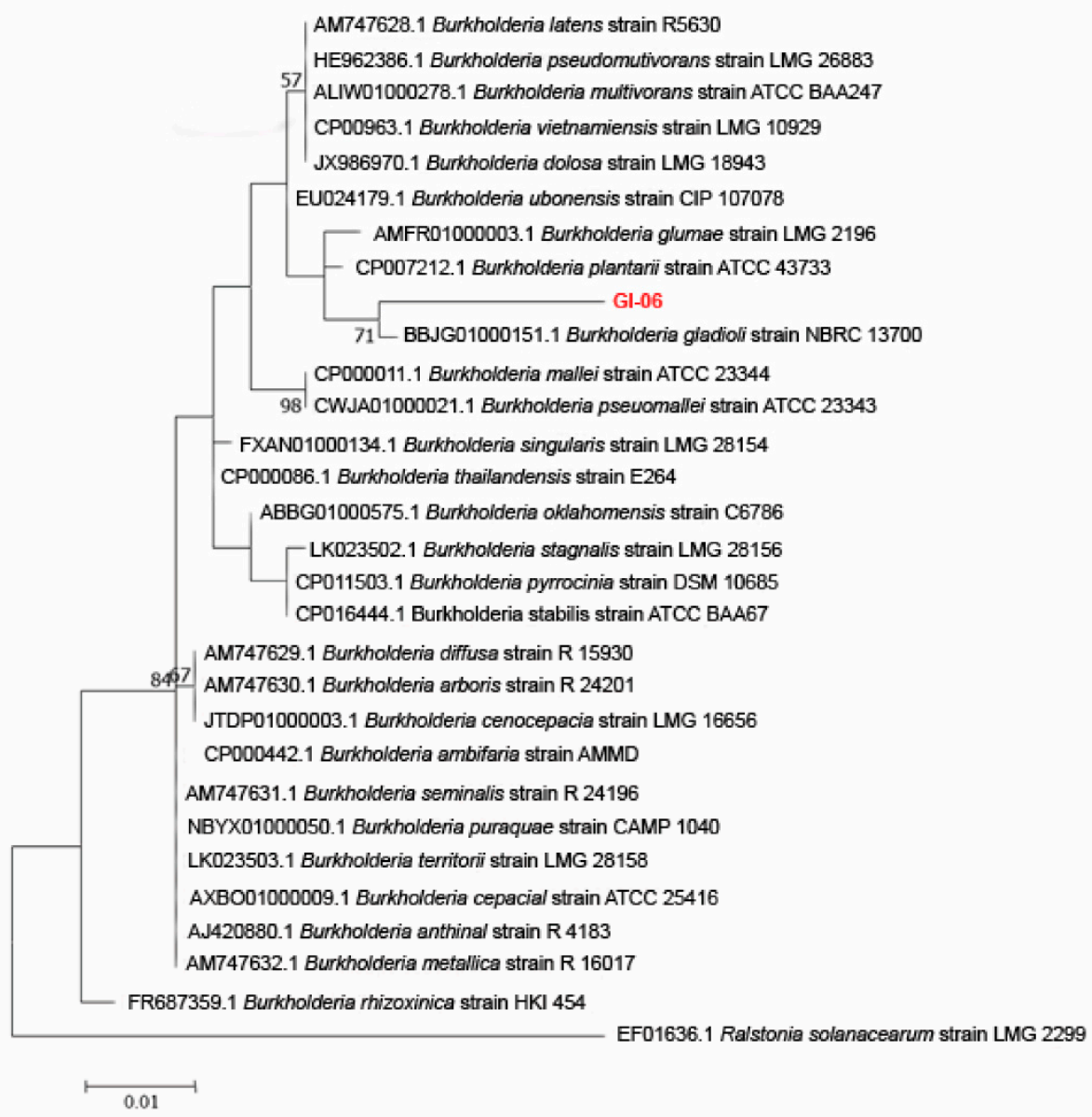

Figure 4. Maximum-likelihood phylogenetic tree constructed using the 16S rRNA gene sequences of the strain GI-06 and selected database sequences in the genus Burkholderia. The phylogenetic relationship was deduced using the Tamura-Nei model and the maximum likelihood approach (1993). Bootstrap values are expressed as a percentage of 1000 replicates; values less than $50 \%$ are not given. Ralstonia solanacearum strain LMG2299, EF016361.1 was employed as outgroup. A total of 0.01 substitutions per nucleotide location are shown in the bar. A total of 31 nucleotide sequences were examined. Gaps and missing data were removed from all positions. The total number of places in the final dataset was 95 . The sequence from the analyzed endophytic bacterial strain is in red. 


\subsection{Biochemical Characterization of Endophytic Bacterial Isolates}

\subsubsection{Catalase Test}

Four out of the five analyzed endophytic bacterial strains showed positive results of catalase activity. The positive catalase activity was shown by GI-6, S-5, GI-1, and S-7, while AH-1 was catalase-negative (Supplementary Figure S1 and Table S1).

\subsubsection{Indole Acetic Acid Production Potential of the Isolated Strains}

Isolate GI-6 showed the highest IAA activity (16.77), while the lowest was recorded for the strain GI-1 (8.45), as shown in Figure 5 and Supplementary Figure S2.

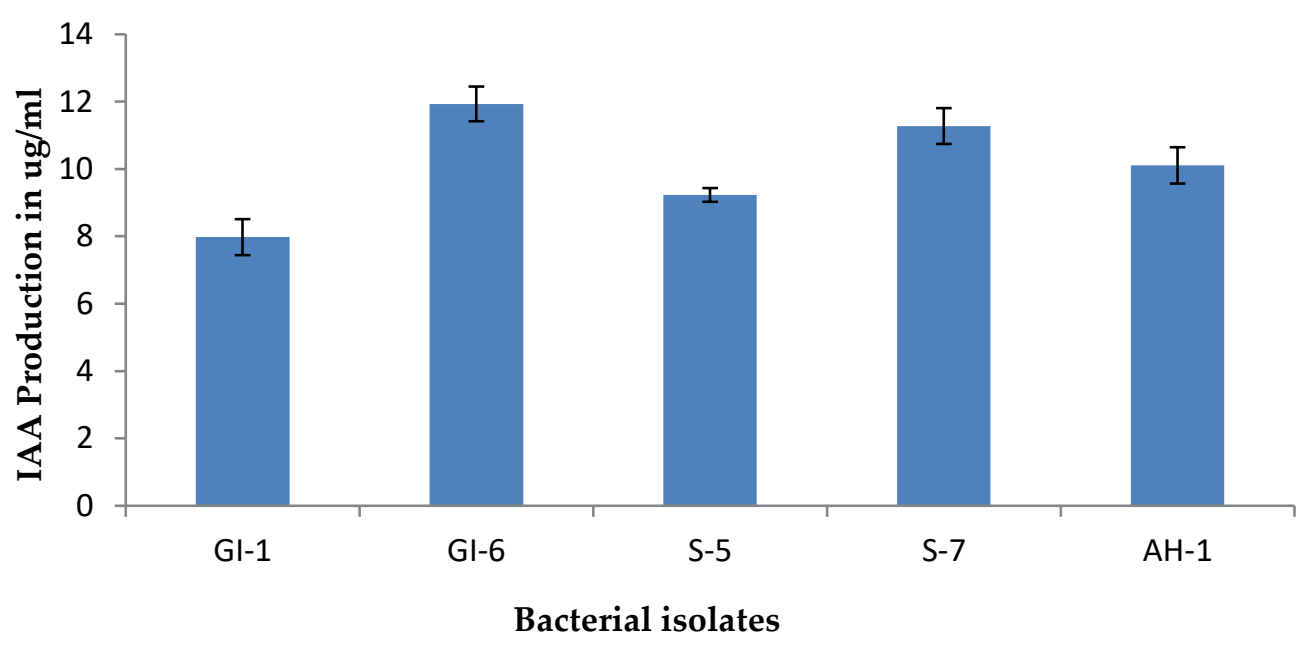

Figure 5. IAA production of the isolated strains. Data are averages \pm SD values.

\subsubsection{Siderophore Production Potential of the Isolated Endophytic Bacterial Strains}

Two endophytic strains out of five grew on CAS agar medium. Isolates GI-6 and AH-1 showed promising results for siderophore production in the form of an orange halo around the colonies. Siderophore development was considered negative in isolates that showed no color change around the edge of the colonies (Figure 6).

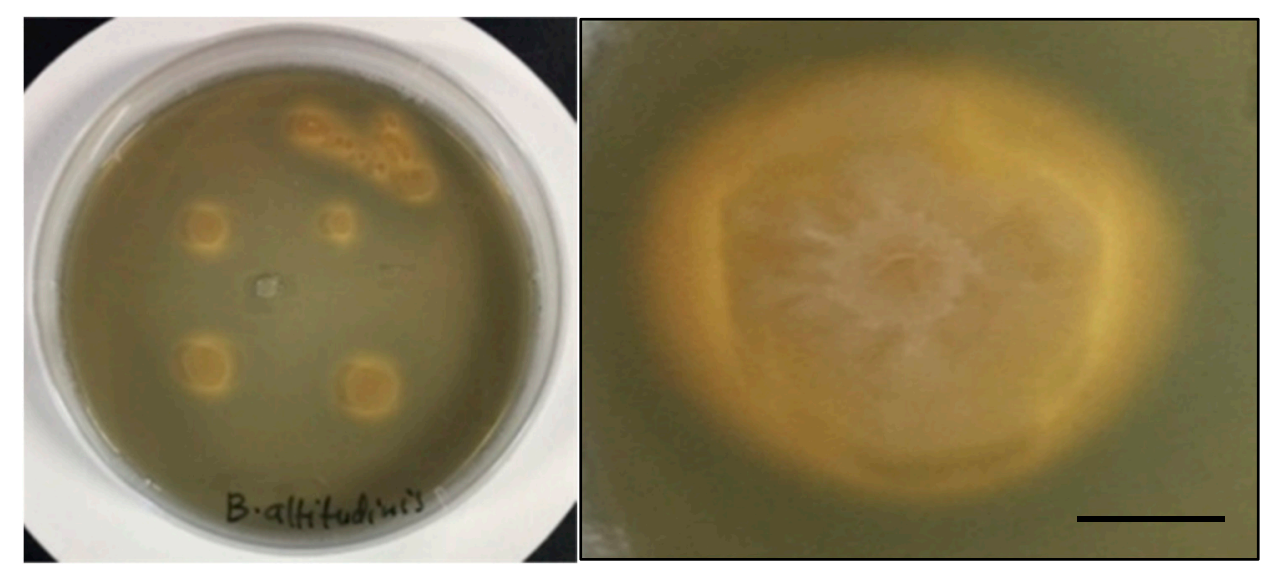

Figure 6. Siderophore production activity of the isolated strains. Overview of various colonies growing in a capsule (left) and detail of a single colony showing the typical yellow-orange halo (right) are provided. Scale bar $2 \mathrm{~mm}$.

The formation of a yellow-to-orange halo around the growth edge indicated that the siderophores produced by the bacterial strains started iron chelation. In fact, the capacity of the siderophore to remove the iron from the dye complex results in the observed color change. By sequestering usable iron, these siderophore-producing endophytes minimize 
the accessibility of iron to iron-requiring phytopathogens. As a result, they indirectly boost plant growth. The ability of the analyzed strains to produce siderophores at various iron citrate concentrations was checked. All strains produced siderophores, and the concentration varied among the strains. However, increasing the Fe (III) citrate concentration in the medium negatively impacted the siderophore accumulation, which was more pronounced in strains, S-5, S-7, and AH-1 (Figure 7 and Supplementary Table S1).

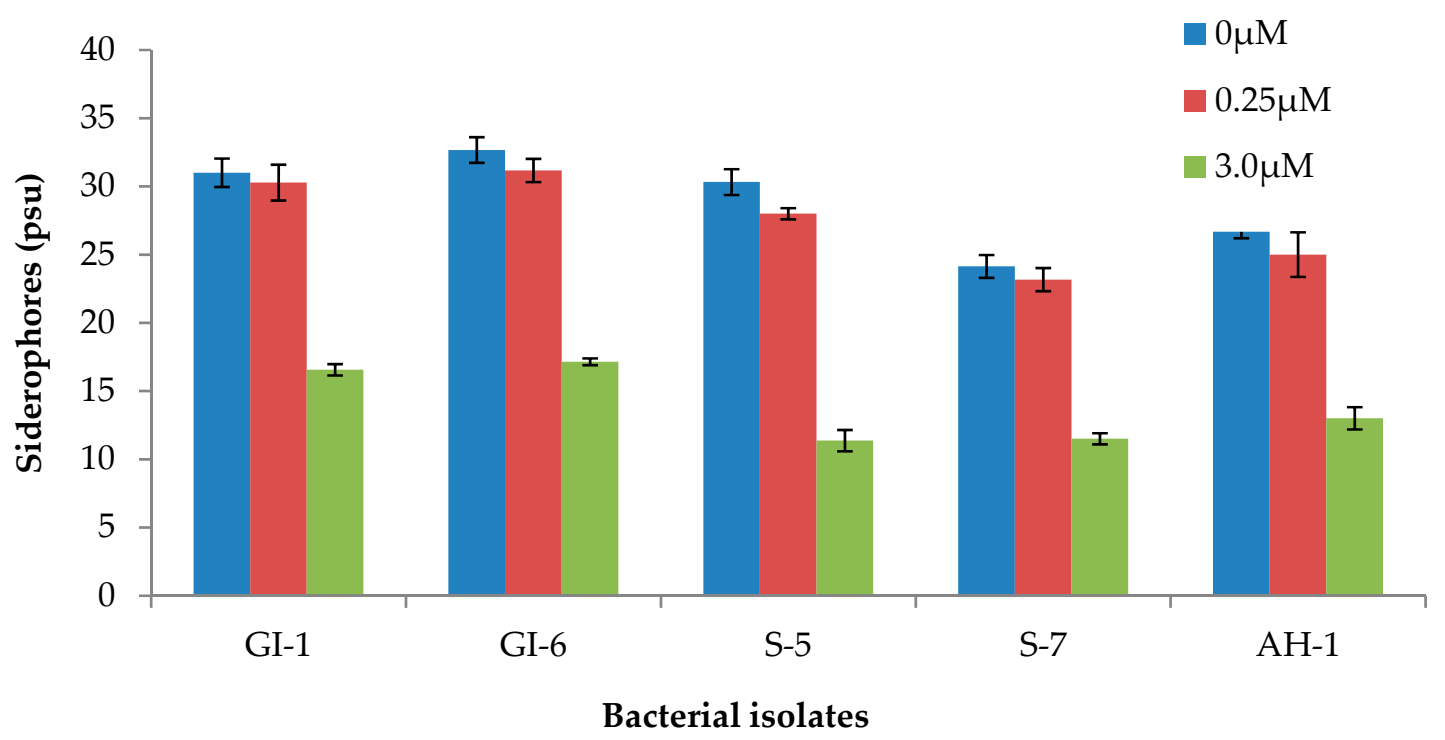

Figure 7. Siderophore production by the bacterial isolates at various Fe (III) citrate concentration. Data are averages \pm SD.

\subsubsection{Phosphorous Solubilization}

The phosphorus solubilization test showed positive results for three isolates (GI-1, GI-6, and S-5) out of five. Endophytic strains expanded on the medium for over $24 \mathrm{~h}$ and resulted in hallow zones around each colony, providing evidence of the isolated strain's ability to use the inorganic phosphate present in the medium. This test was completed over 8 to 10 days. Zone formations could be seen with the naked eye. Isolated Siran was used as a negative control. All the three positive isolates developed a clear zone with a diameter between 1.5 and $3.5 \mathrm{~mm}$. The solubilization index was calculated by the formula: $\mathrm{SI}=$ clearing zone + colony diameter/colony diameter. Isolate Ghaneemat IBGE formed the maximum solubilization zone $(3.5 \mathrm{~mm}$ ) (Figure 8, Table 2 and Supplementary Table S1).
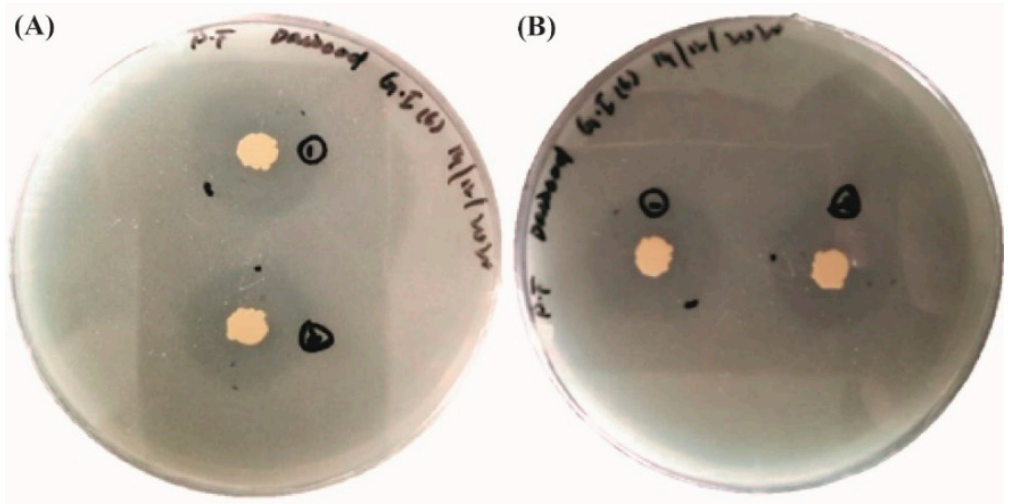

Figure 8. Phosphorous solubilization activity of the isolated strains (A) GI-1; (B) GI-6. 
Table 2. Phosphorous solubilization activity of the isolated strains.

\begin{tabular}{cccc}
\hline Isolates & $\begin{array}{c}\text { Halo Zone Diameter } \\
(\mathbf{m m})\end{array}$ & $\begin{array}{c}\text { Colony Diameter } \\
(\mathbf{m m})\end{array}$ & $\begin{array}{c}\text { Solubilization } \\
\text { Index }\end{array}$ \\
\hline GI-1 & $2.90 \pm 0.21$ & $1.00 \pm 0.05$ & 2.90 \\
GI-6 & $3.50 \pm 0.26$ & $1.10 \pm 0.08$ & 4.18 \\
S-7 & $3.10 \pm 0.18$ & $1.85 \pm 0.12$ & 2.65 \\
S-5 & $3.50 \pm 0.24$ & $1.10 \pm 0.09$ & 4.18 \\
HA-1 & $2.70 \pm 0.14$ & $1.10 \pm 0.10$ & 3.45 \\
\hline
\end{tabular}

\subsubsection{Nitrogen Assimilation Potential of the Isolates}

Bacterial isolates AH-1, GI-6, and S-5 were positive for nitrogen assimilation, which caused a change in the medium. The transformation of a clear medium to a turbid one was regarded as a success. Isolate $\mathrm{AH}-1$ had the best result, followed by isolate GI-6. Positive isolates were compared to a control which consisted of a nitrogen-free medium with no inoculum. The turbidity of a medium increased upon the expansion of tested isolates, thus implying higher nitrogen assimilation (Supplementary Figures S3 and S4, Table S2). A 23-day long period was necessary to obtain clear results.

\subsubsection{Antimicrobial Activity of the Isolated Strains against Pathogenic Bacteria}

The selected endophytic bacteria from the three varieties of wheat seeds were studied to determine their in vitro inhibitory activity against the pathogenic bacteria Klebsiella pneumonia, Escherichia coli, and Staphylococcus aureus, and the non-pathogenic bacterium Bacillus subtilis. The five isolates (GI-6, GI, S. S-7, S-5, and AH-1) appeared to have a broad spectrum of antimicrobial activity in vitro. Indeed, all the analyzed endophytic strains exhibited substantial growth inhibition of the pathogenic bacterial strains, while Ciprofloxacin showed the highest inhibitory effect. The highest antimicrobial activity among the tested strains was determined with the isolates of GI- 6 against K. pneumonia, while the second strongest inhibitory effect of GI- 6 was against E. coli. The isolate S-7 showed the least antimicrobial activity among the studied isolates against the pathogenic bacterium B. subtilis. The different doses of all the isolates extracted against the tested microbes were observed to produce varying zones of inhibition ranging from $25 \mathrm{mM}$ to $5 \mathrm{mM}$ (Figure 9).

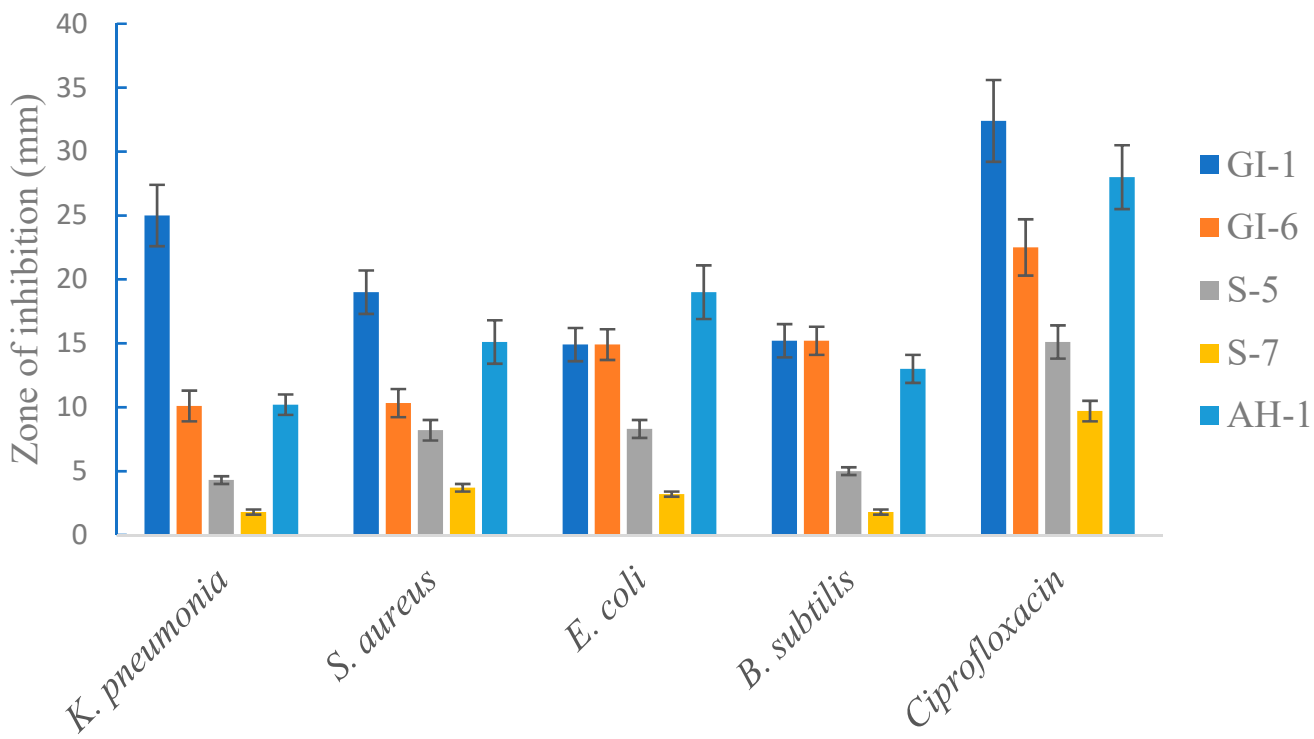

Figure 9. Antimicrobial activity of the isolated strains against selected pathogenic and non-pathogenic bacteria. Ciprofloxacin was used as a positive control. Data are averages \pm SD values. 


\subsection{Screening of Endophytic Isolates for Drought and Salinity Stress Resistance}

Overall, the analyzed bacterial isolates showed significant resistance to the adverse effects of both drought and salinity stress. The increasing PEG concentrations had a clear negative impact on the growth of bacterial strains GI-1, S-5, S-7, and AH-1, whereas the GI-6 strain was less affected by elevated PEG concentration. This bacterial strain growth remained continuous (OD value ranged from 1.2-1.4 on day 1, 1.6-1.8 on day 2, 1.7-2.2 on day 3) upon all applied PEG concentrations, suggesting resistance to drought stress, as indicated in Figure 10. Similarly, bacterial strain GI-6 maintained consistent growth upon all applied concentrations of salts in LB media (Figure 11). On the contrary, increasing salt concentration reduced GI-1, S-5, S-7, and AH-1 strain growth. Overall, the results revealed that the strain GI-6 possessed a much stronger capability to tolerate both drought and salt stress than the other tested strains.

A

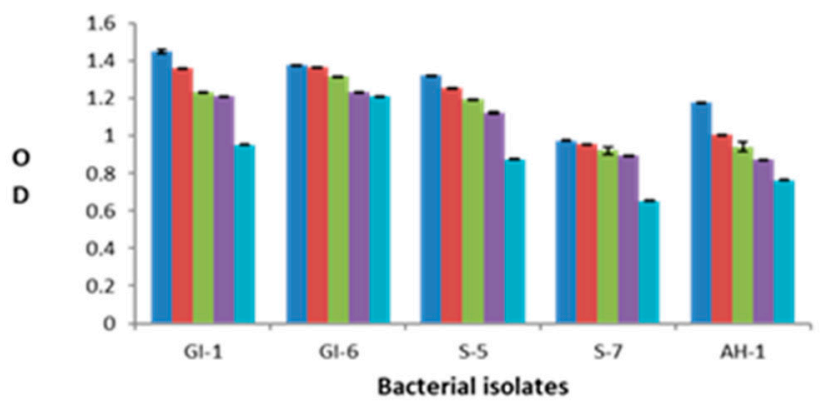

B

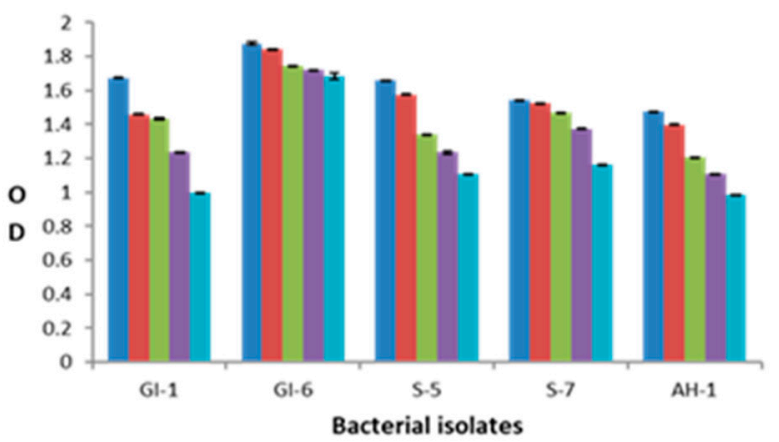

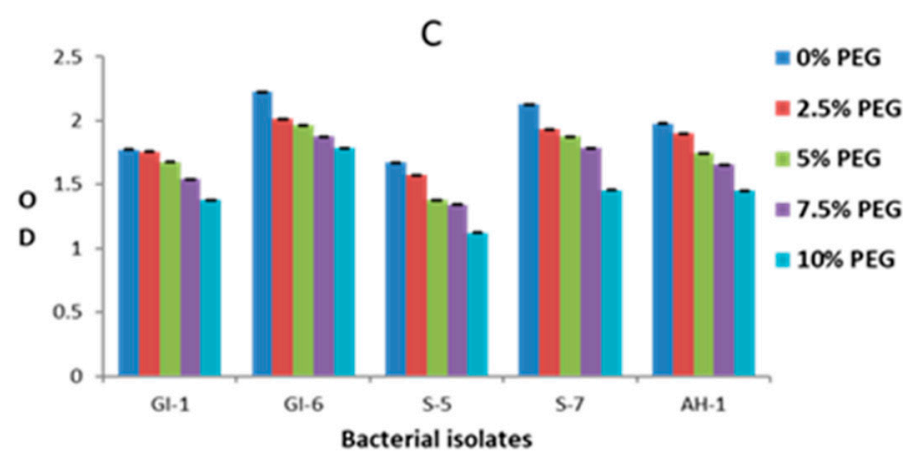

Figure 10. Bacterial growth, estimated by measuring the optical density (OD), against drought stress, at different poly ethylene glycol (PEG) concentrations, in the first three days: (A) day 1, (B) day 2, (C) day 3. 
A

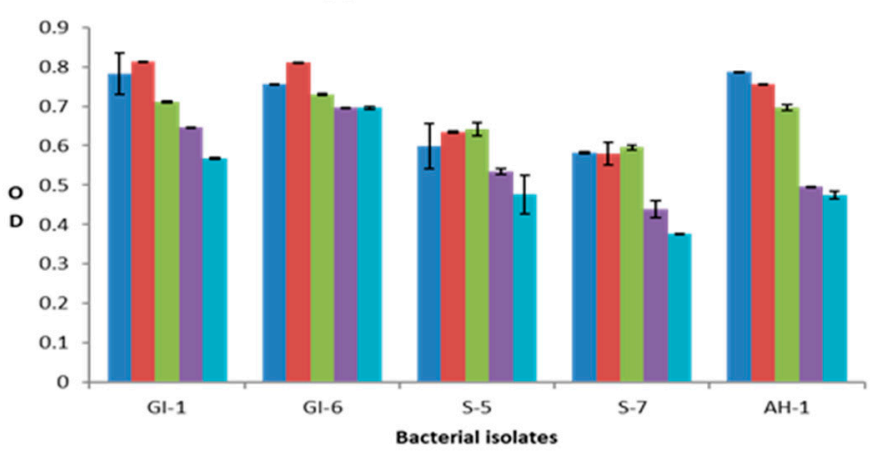

B

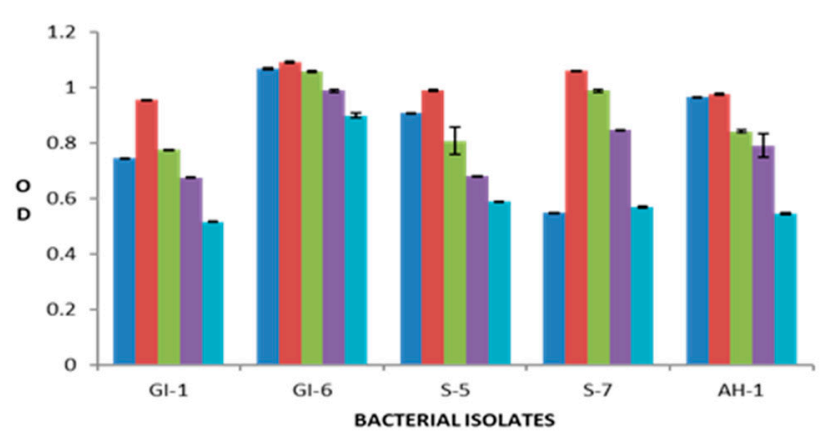

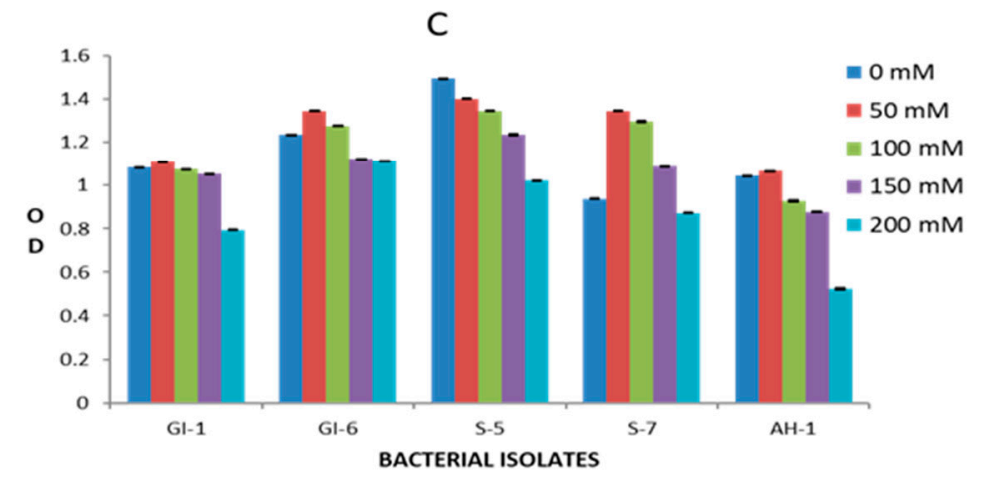

Figure 11. Bacterial growth, estimated by measuring the optical density (OD), against salinity stress, at different $\mathrm{NaCl}$ concentrations (0-200 mM), in the first three days: (A) day 1, (B) day 2, (C) day 3.

\subsection{GI-6 Isolate Growth-Promoting Effect on Wheat Plants}

Seeds inoculated with GI-6 endophyte showed a dramatic increase in overall plant development compared to control plants. Most of the studied growth parameters were significantly $(p \leq 0.05)$ higher in the inoculated plants than in the non-inoculated controls (Table 3). Plant height was increased in the inoculated Imdad wheat variety plants $(35.5 \pm 1.08 \mathrm{~cm} ; p=0.02)$, compared to the control $(27 \pm 0.86 \mathrm{~cm})$. The number of grains per spike and root length were significantly higher for the inoculated plants $(15 \pm 1.08$; $p<0.05$ and $13.3 \pm 1.69 \mathrm{~cm} ; p<0.05$, respectively) than the control (Table 3). Other growth parameters also increased in the inoculated plants, though the differences with the control were minor. The different growth parameters of inoculated and non-inoculated plants are illustrated in Figure 12.

Table 3. Plant growth promotion in wheat variety Imdad plants inoculated with GI-6 bacterial strain.

\begin{tabular}{cccccc}
\hline Treatment & Plant Height $\mathbf{( c m )}$ & Spike Length & Leaf Length & Root Length & $\begin{array}{c}\text { Number of Grains } \\
\text { per Spike }\end{array}$ \\
\hline Control plants & $27.0 \pm 0.82^{\mathrm{a}}$ & $5.8 \pm 0.64^{\mathrm{a}}$ & $10.4 \pm 0.94^{\mathrm{a}}$ & $8.06 \pm 2.05^{\mathrm{a}}$ & $12.0 \pm 0.87^{\mathrm{a}}$ \\
Inoculated plants & $35.5 \pm 1.08^{\mathrm{b}}$ & $7.0 \pm 1.63^{\mathrm{a}}$ & $15.0 \pm 0.81^{\mathrm{b}}$ & $13.3 \pm 1.69^{\mathrm{a}}$ & $15.0 \pm 1.08^{\mathrm{a}}$ \\
\hline
\end{tabular}

Means are averages $\pm \mathrm{SD}(n=5)$. Values in a column with different letters 'a' and 'b' are significantly different by Student's $t$ test at $(p \leq 0.05)$. Controls are non-inoculated plants. 

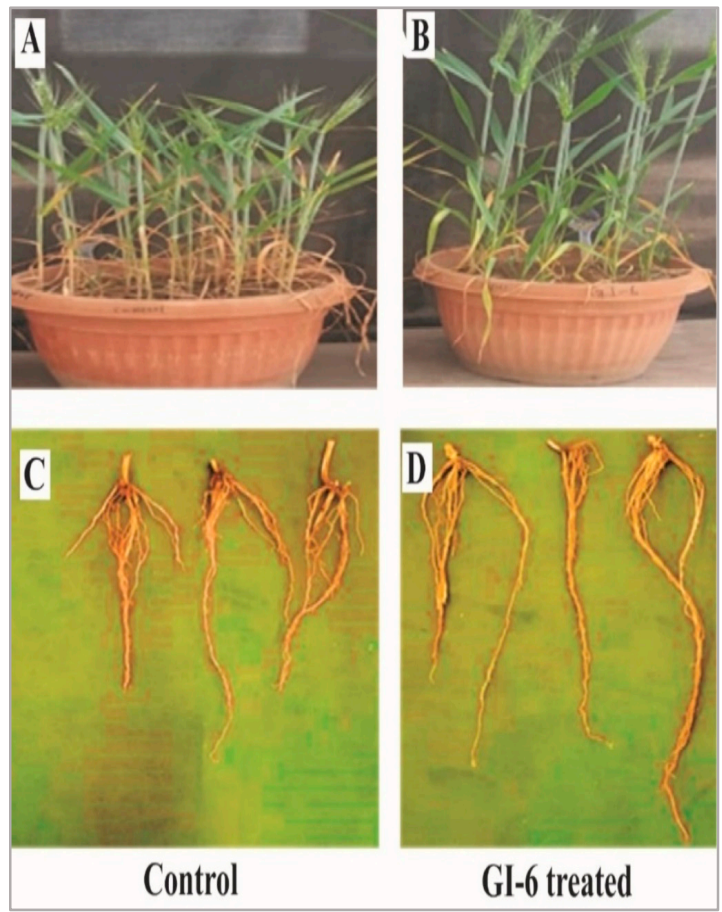

Figure 12. Phenotypic expression of the wheat variety Imdad plants: the height of plants inoculated with the endophytic strain GI-6 was increased (B) compared to non-inoculated control plants (A). Root length of GI-6 treated plants (D) was also significantly higher than non-inoculated control plants (C).

\section{Discussion}

In the present study, endophytic bacteria were isolated from the seeds of different wheat varieties with the aim of evaluating their potential application in the development of bio-fertilizers. Five different bacterial strains designated as AH-1, S-5, S-7, GI-1, and GI-6 were isolated from three wheat varieties, i.e., Atta-Habib, Siren, and Ghaneemat-IBGE. Phylogenetic analysis showed that the sequences from the isolated endophytic bacterial strains had close homologies with Bacillus altitudinis, B. aryabhattai, B. wiedmannii, Pseudomonas aeruginosa, and Burkholderia gladioli. Several previous studies reported on the isolation of these bacterial species from several plants [29] such as rice, cotton, cucumber, sugar beet and potatoes. These endophytes have previously shown plant growth-promoting traits, such as IAA production, combined with siderophores, catalase, phosphate solubilization, and antimicrobial effects [30]. Similarly, the bacterial strains isolated in the present study showed several clear plant growth-promoting traits.

The catalase activities of endophytic bacterial strains obtained from wheat seeds in this study were different. Wheat endophytic bacteria had previously been found to be catalase positive [31]. In addition, a previous study found catalase production in $87.59 \%$ of bacterial strains isolated from a medicinal plant, Ocimum sp., endophyte [32].

All the analyzed endophytic strains showed IAA production, with the two strains GI-1 and GI-6 designated as Pseudomonas aeruginosa and Burkholderia gladioli, isolated from Ghaneemat-IBGE exhibiting maximum IAA production. Several studies have shown the ability of P. aeruginosa and B. gladioli to produce high concentrations of IAA, which have led to these two bacterial species being considered important endophytes for directly promoting the growth of associated plants [33]. Indeed, IAA is the most important phytohormone that directly promotes the growth of plants and microbes. Root growth and root length can be increased by endophytic bacteria with IAA-producing ability, resulting in a greater root surface area, which allows the plant to acquire more nutrients from the soil [34]. Our 
results support previous findings that IAA generation by endophytic bacterial species is beneficial to plant growth.

From our analysis, all the bacterial strains developed siderophores. However, qualitative and quantitative methods revealed that the three isolates, GI-1, GI-6, and S-5, had comparatively higher siderophore concentrations. Under various iron conditions, quantitative examinations of the siderophores were performed. When there was no Fe (III) citrate in the medium, siderophore development was at its peak. Similarly, increased iron concentrations in the medium had a negative effect on the synthesis of siderophores in a previous study by Nair et al. [35]. Our findings agree with previous research that found an inverse relationship between different iron concentrations and siderophore production [36,37]. Iron is abundant in the soil, mainly in the form of insoluble $\mathrm{Fe}^{3+}$ oxyhydroxides that plants and microbes cannot utilize. Plant-associated microbes use ferric reductases to convert $\mathrm{Fe}^{3+}$ to $\mathrm{Fe}^{2+}$ or to solubilize it with extracellular $\mathrm{Fe}^{3+}$ chelators called siderophores, which are released when soil iron levels are low [38]. This soluble $\mathrm{Fe}^{3+}-$ siderophore complex is accessible to both plants and microbes [39]. Siderophore formation has been previously observed in isolated PGP rhizobacteria such as Bacillus sp., Pseudomonas sp., and Paenibacillus sp. [40]. Under various iron conditions, the isolated strain Paenibacillus polymyxa SQR-21 developed siderophores [41].

In the current investigation, the bacterial isolates AH-1, GI-6, and S-5 were found positive for nitrogen assimilation, with $\mathrm{AH}-1$ demonstrating the best result, followed by GI-6, which implies their ability to fix atmospheric nitrogen. One of the most abundant, necessary, and vital elements for plant growth and development is nitrogen. The ability to fix atmospheric nitrogen has been discovered in most plant growth-promoting bacteria, including Bacillus, Pseudomonas, and Burkholderia species. In some instances, the ability of endophytic bacteria to fix nitrogen specifically led to positive effects on inoculated target plants [42]. The latter study [42] reported an increase in the growth of lodge pole pine inoculated with P. polymyxa (P2b-2R) in N-deficient soil. Furthermore, it has been demonstrated that the nitrogen fixation and growth promotion of canola (Brassica napus L.) were achieved by inoculation with the strain P2b-2R of P. polymyxa [43].

Phosphate solubilization capacity was found in our isolated strains. This capacity was particularly strong in the two strains GI-6 and S-5. Solubilization of phosphate is one of the main characteristics of endophytic strains that enhance the growth of associated plants, according to previous research [44]. In the latter study, the ability to dissolve phosphate was identified in Paenibacillus spp. strains from both mycorrhizal and non-mycorrhizal cucumber plants.

Endophytic bacteria possess the ability to inhibit the growth of pathogenic bacteria and fungi. Several endophytic bacteria have previously shown antagonistic effects against plant pathogens [45]. Similar results were reported in our study, where 4 out of 5 analyzed bacterial endophytes (GI-1, GI-6, AH-1, and S-5) showed clear antimicrobial activity against tested pathogenic bacteria in a dose dependent manner. The highest antibacterial activity was observed for GI-6 against Klebsiella pneumonia. A previous investigation has reported a potent activity of Gladiolin, an antibiotic produced by Burkholderia gladioli, against Mycobacterium tuberculosis [46].

Salinity tolerance of the isolated endophytic strains was evaluated under elevated salt concentrations and detected in all five strains tested. In previous studies on endophytic microbes from desert-dwelling plants, high salt tolerance of bacterial endophytes was also observed [47]. Zhao et al. [48] have proposed that bacterial endophytes live and multiply within the plant where the salt concentration is relatively low due to osmotic stress and toxic ions. In this study, the endophytic bacterial strains showed utmost resistance to various concentrations of salt, which may be due to a neutralization effect.

Due to their unpredictable and devastating impacts on plant function as a whole, abiotic stresses such as salt and drought have been highlighted as key variables that impede food production $[49,50]$. Under limited irrigation, endophytic bacterial strains Bacillus pumilus and B. subtilis can help plants to develop faster [49]. Moreover, the use of 
bacterial endophytes in enhancing tomato growth under salt stress has been reported [51]. We tested the plant growth-promoting characteristics of our isolated strain GI-6 in the inoculation experiments, which involved seeds of the wheat variety Imdad. The inoculated plants showed better growth compared to that of the non-inoculated control plants. Some growth parameters were significantly improved in the inoculated plants than in the control plants. Similar results were produced when endophytic strains of Bacillus velezensis and $B$. stratosphericus were applied to plants of Lilium [21,42]. The latter studies reported that the improved growth of Lilium plants upon inoculation with the endophytes might be due to the plant growth-promoting potential of the inoculated bacteria. Similarly, in the present study, the growth improvement of inoculated wheat plants might be due to the biochemical and growth promoting effects of the endophytic strain GI-6.

\section{Conclusions}

We performed a comprehensive phylogenetic and biochemical analysis of five endophytic bacterial strains isolated from the seeds of 3 different wheat varieties. The analyzed strains, belonging to the genera Bacillus, Pseudomonas and Burkholderia, showed different levels of catalase activity, nitrogen assimilation, phosphate solubilization, and the ability to produce IAA and siderophores, which makes them strong candidates for exploitation as plant growth-promoting microbes. We found antimicrobial activity against pathogenic bacteria in all the studied strains, thus showing their potential effect to enhance diseaseresistance in plant of high economic value. Moreover, the analyzed endophytic bacteria showed significant resistance to drought and salinity stress, which are well known issues in agrobusiness, causing a critical loss of crop yield every year [52]. Among all the investigated bacterial isolates, the most promising strain for application in sustainable agriculture was GI-6, which showed a clear growth-promoting effect on the inoculated wheat plants. The endophytic microbes analyzed in our study may represent an important, environmentalfriendly alternative to chemical fertilizers and pesticides to enhance plant growth and yield under environmental stress, thus supporting the development of sustainable agriculture.

Supplementary Materials: The following are available online at https://www.mdpi.com/article/10 $.3390 /$ microorganisms10010021/s1, Table S1: Biochemical characterization of the endophytic bacteria isolated from different varieties of wheat, Table S2: Nitrogen assimilation activity of isolated strains, Figure S1: Catalase activity of the isolated strains, Figure S2: IAA production activity of the isolated strains, Figure S3: Nitrogen assimilation of isolated strains on Ashby N free media, Figure S4: Nitrogen assimilation of isolated strains on Jensen $\mathrm{N}$ free agar media.

Author Contributions: Conceptualization, D.S., M.S.K. and L.P.; methodology, D.S.; data curation, D.S., S.A., H.A. and L.P.; supervision, M.S.K. and L.P.; manuscript preparation, D.S., S.A. and L.P. All authors have read and agreed to the published version of the manuscript.

Funding: This research received no external funding.

Institutional Review Board Statement: Not applicable.

Informed Consent Statement: Not applicable.

Data Availability Statement: Data presented in this study can be found as part of the manuscript, and in the Supplementary Materials.

Conflicts of Interest: The authors declare no conflict of interest.

\section{References}

1. Khatri, N.; Tyagi, S. Influences of natural and anthropogenic factors on surface and groundwater quality in rural and urban areas. Front. Life Sci. 2015, 8, 23-39. [CrossRef]

2. Vurukonda, S.S.K.P.; Giovanardi, D.; Stefani, E. Plant growth promoting and biocontrol activity of Streptomyces spp. as endophytes. Int. J. Mol. Sci. 2018, 19, 952. [CrossRef]

3. Zhao, J.; Shan, T.; Mou, Y.; Zhou, L. Plant-derived bioactive compounds produced by endophytic fungi. Mini Rev. Med. Chem. 2011, 11, 159-168. [CrossRef] [PubMed] 
4. Jha, P.N.; Gupta, G.; Jha, P.; Mehrotra, R. Association of rhizospheric/endophytic bacteria with plants: A potential gateway to sustainable agriculture. Greener J. Agric. Sci. 2013, 3, 73-84.

5. Sahay, H.; Yadav, A.N.; Singh, A.K.; Singh, S.; Kaushik, R.; Saxena, A.K. Hot springs of Indian Himalayas: Potential sources of microbial diversity and thermostable hydrolytic enzymes. 3 Biotech 2017, 7, 118. [CrossRef] [PubMed]

6. Hardoim, P.R.; van Overbeek, L.S.; van Elsas, J.D. Properties of bacterial endophytes and their proposed role in plant growth. Trends Microbiol. 2008, 16, 463-471. [CrossRef] [PubMed]

7. Giraldo, P.; Benavente, E.; Manzano-Agugliaro, F.; Gimenez, E. Worldwide research trends on wheat and barley: A bibliometric comparative analysis. Agronomy 2019, 9, 352. [CrossRef]

8. Umer, M.F.; Zofeen, S.; Hu, W.; Qi, X.; Zhuang, G. Spatiotemporal clustering analysis of Expanded Program on Immunization (EPI) vaccination coverage in Pakistan. Sci. Rep. 2020, 10, 10980. [CrossRef]

9. Rahman, M.S.; Quadir, Q.F.; Rahman, A.; Asha, M.N.; Chowdhury, M.A.K. Screening and characterization of Phosphorus solubilizing Bacteria and their effect on Rice seedlings. Res. Agric. Livest. Fish. 2014, 1, 27-35. [CrossRef]

10. Shrivastava, P.; Kumar, R. Soil salinity: A serious environmental issue and plant growth promoting bacteria as one of the tools for its alleviation. Saudi J. Biol. Sci. 2015, 22, 123-131. [CrossRef] [PubMed]

11. Ashraf, M. Biotechnological approach of improving plant salt tolerance using antioxidants as markers. Biotechnol. Adv. 2009, 27, 84-93. [CrossRef]

12. Prasad, P.; Staggenborg, S.; Ristic, Z. Impacts of Drought and/or Heat Stress on Physiological, Developmental, Growth, and Yield Processes of Crop Plants; ASA-CSSA-SSSA: Madison, WI, USA, 2008; Volume 1, pp. 301-355.

13. Fahad, S.; Bajwa, A.A.; Nazir, U.; Anjum, S.A.; Farooq, A.; Zohaib, A.; Sadia, S.; Nasim, W.; Adkins, S.; Saud, S. Crop production under drought and heat stress: Plant responses and management options. Front. Plant Sci. 2017, 8, 1147. [CrossRef]

14. Shangguan, Z.; Shao, M.; Dyckmans, J. Interaction of osmotic adjustment and photosynthesis in winter wheat under soil drought. J. Plant Physiol. 1999, 154, 753-758. [CrossRef]

15. Francois, L.E.; Grieve, C.M.; Maas, E.V.; Lesch, S.M. Time of salt stress affects growth and yield components of irrigated wheat Agron. J. 1994, 86, 100-107. [CrossRef]

16. Verslues, P.E.; Agarwal, M.; Katiyar-Agarwal, S.; Zhu, J.; Zhu, J.K. Methods and concepts in quantifying resistance to drought, salt and freezing, abiotic stresses that affect plant water status. Plant J. 2006, 45, 523-539. [CrossRef]

17. De Souza Vandenberghe, L.P.; Garcia, L.M.B.; Rodrigues, C.; Camara, M.C.; de Melo Pereira, G.V.; de Oliveira, J.; Soccol, C.R Potential applications of plant probiotic microorganisms in agriculture and forestry. AIMS Microbiol. 2017, 3, 629. [CrossRef]

18. Herrera, S.D.; Grossi, C.; Zawoznik, M.; Groppa, M.D. Wheat seeds harbour bacterial endophytes with potential as plant growth promoters and biocontrol agents of Fusarium graminearum. Microbiol. Res. 2016, 186, 37-43. [CrossRef] [PubMed]

19. Somasegaran, P.; Hoben, H.J. Quantifying the growth of rhizobia. In Handbook for Rhizobia; Springer: New York, NY, USA, 1994; pp. $47-57$.

20. Sambrook, J.; Fritsch, E.F.; Maniatis, T. Molecular Cloning: A Laboratory Manual; Cold Spring Harbor Laboratory Press: Long Island, NY, USA, 1989.

21. Khan, M.S.; Gao, J.; Zhang, M.; Chen, X.; Du, Y.; Yang, F.; Xue, J.; Zhang, X. Isolation and characterization of plant growthpromoting endophytic bacteria Bacillus stratosphericus LW-03 from Lilium wardii. 3 Biotech 2020, 10, 305. [CrossRef]

22. Kumar, S.; Stecher, G.; Tamura, K. MEGA7: Molecular evolutionary genetics analysis version 7.0 for bigger datasets. Mol. Biol. Evol. 2016, 33, 1870-1874. [CrossRef] [PubMed]

23. Sinha, E.; Michalak, A.; Balaji, V. Eutrophication will increase during the 21st century as a result of precipitation changes. Science 2017, 357, 405-408. [CrossRef]

24. Patten, C.L.; Glick, B.R. Role of Pseudomonas putida indoleacetic acid in development of the host plant root system. Appl. Environ. Microbiol. 2002, 68, 3795-3801. [CrossRef] [PubMed]

25. Lanyi, B. 1 Classical and rapid identification methods for medically important bacteria. J. Microbiol. Methods 1988, 19, 1-67. [CrossRef]

26. Li, X.; Geng, X.; Xie, R.; Fu, L.; Jiang, J.; Gao, L.; Sun, J. The endophytic bacteria isolated from elephant grass (Pennisetum purpureum Schumach) promote plant growth and enhance salt tolerance of Hybrid Pennisetum. Biotechnol. Biofuels 2016, 9, 190. [CrossRef]

27. Pirhadi, M.; Enayatizamir, N.; Motamedi, H.; Sorkheh, K. Screening of salt tolerant sugarcane endophytic bacteria with potassium and zinc for their solubilizing and antifungal activity. Biosci. Biotechnol. Res. Commun. 2016, 9, 530-538. [CrossRef]

28. Sandhya, S.; Preetha, K.; Vijayan, K. Phylogenetic diversity of culturable bacteria in Chaetoceros gracilis mass culture system of a marine finfish hatchery. J. Mar. Biol. Assoc. India 2018, 59, 12-18. [CrossRef]

29. Khaskheli, M.A.; Wu, L.; Chen, G.; Chen, L.; Hussain, S.; Song, D.; Liu, S.; Feng, G. Isolation and characterization of root-associated bacterial endophytes and their biocontrol potential against major fungal phytopathogens of rice (Oryza sativa L.). Pathogens 2020, 9, 172. [CrossRef]

30. Kumar, P.; Dubey, R.; Maheshwari, D. Bacillus strains isolated from rhizosphere showed plant growth promoting and antagonistic activity against phytopathogens. Microbiol. Res. 2012, 167, 493-499. [CrossRef]

31. Eid, A.M.; Salim, S.S.; Hassan, S.E.-D.; Ismail, M.A.; Fouda, A. Role of endophytes in plant health and abiotic stress management. In Microbiome in Plant Health and Disease; Springer: Singapore, 2019; pp. 119-144. [CrossRef] 
32. Saharan, B.; Shuchita, V. Evaluation of rhizospheric bacteria from Ocimum sp. as potential PGPR. J. Microb. Biochem. Technol. 2015, 7, 88-95. [CrossRef]

33. Walitang, D.I.; Kim, K.; Madhaiyan, M.; Kim, Y.K.; Kang, Y.; Sa, T. Characterizing endophytic competence and plant growth promotion of bacterial endophytes inhabiting the seed endosphere of Rice. BMC Microbiol. 2017, 17, 209. [CrossRef]

34. Souza, R.d.; Ambrosini, A.; Passaglia, L.M. Plant growth-promoting bacteria as inoculants in agricultural soils. Genet. Mol. Biol. 2015, 38, 401-419. [CrossRef]

35. Nair, A.; Juwarkar, A.A.; Singh, S.K. Production and characterization of siderophores and its application in arsenic removal from contaminated soil. Water Air Soil Pollut. 2007, 180, 199-212. [CrossRef]

36. Amin, S.A.; Green, D.H.; Hart, M.C.; Küpper, F.C.; Sunda, W.G.; Carrano, C.J. Photolysis of iron-siderophore chelates promotes bacterial-algal mutualism. Proc. Natl. Acad. Sci. USA 2009, 106, 17071-17076. [CrossRef] [PubMed]

37. Johnstone, T.C.; Nolan, E.M. Beyond iron: Non-classical biological functions of bacterial siderophores. Dalton Trans. 2015, 44, 6320-6339. [CrossRef] [PubMed]

38. Rahman, M.A.; Rahman, M.M.; Maki, T.; Hasegawa, H. The significance of biodegradable methylglycinediacetic acid (MGDA) for iron and arsenic bioavailability and uptake in rice plant. J. Soil Sci. Plant Nutr. 2012, 58, 627-636. [CrossRef]

39. Qi, W.; Zhao, L. Study of the siderophore-producing Trichoderma asperellum Q1 on cucumber growth promotion under salt stress. J. Basic Microbiol. 2013, 53, 355-364. [CrossRef]

40. Goswami, D.; Parmar, S.; Vaghela, H.; Dhandhukia, P.; Thakker, J.N. Describing Paenibacillus mucilaginosus strain N3 as an efficient plant growth promoting rhizobacteria (PGPR). Cogent Food Agric. 2015, 1, 1000714. [CrossRef]

41. Raza, W.; Shen, Q. Growth, $\mathrm{Fe}^{3+}$ reductase activity, and siderophore production by Paenibacillus polymyxa SQR-21 under differential iron conditions. Curr. Microbiol. 2010, 61, 390-395. [CrossRef] [PubMed]

42. Khan, M.S.; Gao, J.; Chen, X.; Zhang, M.; Yang, F.; Du, Y.; Munir, I.; Xue, J.; Zhang, X. Isolation and characterization of plant growth-promoting endophytic bacteria Paenibacillus polymyxa SK1 from Lilium lancifolium. BioMed Res. Int. 2020, $2020,8650957$. [CrossRef]

43. Kour, D.; Rana, K.L.; Yadav, N.; Yadav, A.N.; Kumar, A.; Meena, V.S.; Singh, B.; Chauhan, V.S.; Dhaliwal, H.S.; Saxena, A.K. Rhizospheric microbiomes: Biodiversity, mechanisms of plant growth promotion, and biotechnological applications for sustainable agriculture. In Plant Growth Promoting Rhizobacteria for Agricultural Sustainability; Springer: Singapore, 2019; pp. 19-65. [CrossRef]

44. Rodríguez, H.; Fraga, R. Phosphate solubilizing bacteria and their role in plant growth promotion. Biotechnol. Adv. 1999, 17, 319-339. [CrossRef]

45. Shahzad, R.; Khan, A.L.; Bilal, S.; Asaf, S.; Lee, I.-J. Plant growth-promoting endophytic bacteria versus pathogenic infections: An example of Bacillus amyloliquefaciens RWL-1 and Fusarium oxysporum f. sp. lycopersici in tomato. PeerJ 2017, 5, e3107. [CrossRef] [PubMed]

46. Song, L.; Jenner, M.; Masschelein, J.; Jones, C.; Bull, M.J.; Harris, S.R.; Hartkoorn, R.C.; Vocat, A.; Romero-Canelon, I.; Coupland, P. Discovery and biosynthesis of gladiolin: A Burkholderia gladioli antibiotic with promising activity against Mycobacterium tuberculosis. J. Am. Chem. Soc. 2017, 139, 7974-7981. [CrossRef]

47. Rashid, S.; Charles, T.C.; Glick, B.R. Isolation and characterization of new plant growth-promoting bacterial endophytes. Appl. Soil Ecol. 2012, 61, 217-224. [CrossRef]

48. Zhao, S.; Zhou, N.; Zhao, Z.-Y.; Zhang, K.; Wu, G.-H.; Tian, C.-Y. Isolation of endophytic plant growth-promoting bacteria associated with the halophyte Salicornia europaea and evaluation of their promoting activity under salt stress. Curr. Microbiol. 2016, 73, 574-581. [CrossRef]

49. Fang, Y.; Xiong, L. General mechanisms of drought response and their application in drought resistance improvement in plants. Cell. Mol. Life Sci. 2015, 72, 673-689. [CrossRef] [PubMed]

50. Atkinson, N.J.; Urwin, P.E. The interaction of plant biotic and abiotic stresses: From genes to the field. J. Exp. Bot. 2012, 63, 3523-3543. [CrossRef] [PubMed]

51. Vaishnav, A.; Shukla, A.K.; Sharma, A.; Kumar, R.; Choudhary, D.K. Endophytic bacteria in plant salt stress tolerance: Current and future prospects. J. Plant Growth Regul. 2019, 38, 650-668. [CrossRef]

52. Sagar, A.; Rathore, P.; Ramteke, P.W.; Ramakrishna, W.; Reddy, M.S.; Pecoraro, L. Plant growth promoting rhizobacteria, arbuscular mycorrhizal fungi and their synergistic interactions to counteract the negative effects of saline soil on agriculture: Key macromolecules and mechanisms. Microorganisms 2021, 9, 1491. [CrossRef] [PubMed] 